\title{
How Should Oil Exporters Spend Their Rents?
}

\section{Alan Gelb and Sina Grasmann}

\begin{abstract}
Oil and other mineral rents are, in most countries, owned by producing states on behalf of their citizens. The paper focuses on three questions. First, how should countries take into account the great uncertainty over future export prices in planning their spending programs? Second, how should countries think about the possible range of options for absorbing oil rents, including transferring them to citizen-owners? What expenditures and policies approaches seem to have facilitated efforts to diversify the non-oil economy? Third, what factors seem to have helped some developing countries to avoid the most adverse effects of the "resource curse"? The paper does not address the full range of issues relating to oil and governance, and it also does not address the longer-run question of how much countries should save in response to the exhaustible nature of oil reserves. It argues for approaches that increase public understanding of the need for prudent spending in booms, and for comprehensive consideration of a range of options for using rents. Drawing on the experience of a few successful countries, it points to a number of common factors that seem to be important in enabling countries to obtain a positive payoff from resource wealth. These include a strong concern for social stability and growth, a capable and engaged technocracy, and interests in the non-oil sectors able to act as agents of restraint. Development partners have little direct leverage on oil-exporting countries, but can help through sharing information, disseminating standards and encouraging civil society, especially constituencies with an interest in spending restraint. These activities should be pursued during the slumps to set the foundation for better management during the booms.
\end{abstract}

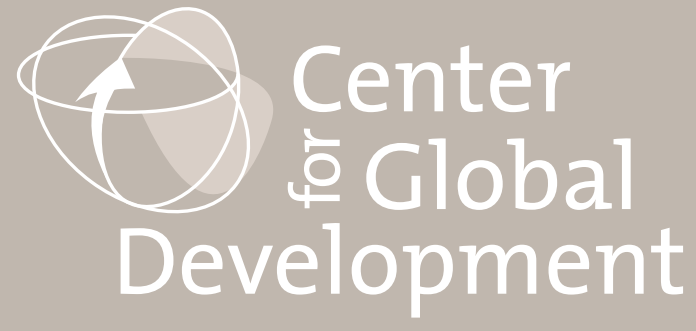

$$
\begin{aligned}
& \text { Working Paper } 221 \\
& \text { August } 2010
\end{aligned}
$$




\title{
How Should Oil Exporters Spend Their Rents?
}

\author{
Alan Gelb
}

Sina Grasmann

Alan Gelb is a senior fellow at the Center for Global Development. Sina Grasmann was formerly at the World Bank. An earlier version of this paper was presented to the 2009 Global Development Network conference in Kuwait. The views expressed in this paper are those of the authors alone.

CGD is grateful for contributions from the Norwegian Ministry of Foreign Affairs and the Australian Agency for International Development in support of this work.

Alan gelb and Sina Grasmann. 2010. "How Should Oil Exporters Spend their Rents?” CGD Working Paper 221. Washington, D.C.: Center for Global Development.

http://www.cgdev.org/content/publications/detail/1424356

Center for Global Development 1800 Massachusetts Ave., NW Washington, DC 20036

202.416 .4000

(f) 202.416 .4050

www.cgdev.org
The Center for Global Development is an independent, nonprofit policy research organization dedicated to reducing global poverty and inequality and to making globalization work for the poor. Use and dissemination of this Working Paper is encouraged; however, reproduced copies may not be used for commercial purposes. Further usage is permitted under the terms of the Creative Commons License.

The views expressed in this paper are those of the author and should not be attributed to the board of directors or funders of the Center for Global Development. 


\section{Introduction}

In 1980 OPEC oil exports peaked at $\$ 600$ billion (constant 2004 dollars) or $\$ 3,500$ per head of population. They then sank as low as $\$ 500$ per head in the 1990s before spiking up again, to $\$ 800$ billion or $\$ 2,500$ per head in the recent boom. This paper considers the use of resource rents, first, over time considering the extreme price volatility of oil markets and, second, the different spending options facing exporters. The question of how to use resource rents for development continues to be important. Although many developing countries have made a successful transition to industrial exports, some 30 are currently highly dependent on hydrocarbons and with new producers such as Ghana and Uganda coming on stream the number is likely to grow. ${ }^{1}$ We do not address directly the long-run issue of saving for future generations.

Research on the "resource curse" has reached a broad consensus. The likely impact of rich natural resource capital on development depends on the levels of two complementary assets: governance or institutional capital and human capital (Karl, 1997, 2003, 2007, 2007a, Ross 2003, Gylfason, 2004, Leiderman and Maloney 2007). Where these are abundant, resource wealth is likely to be a positive factor, where they are scarce, the outcomes from resource finds are likely to be poor. This paper does not address the "upstream" issues of resource contracting, development and taxation, or the wide range of issues relating to the interaction between resource abundance, dependence and governance. While recognizing that these are central, and that governance-related issues will continue to dominate narrower policy choices, at least in the less-well-governed countries, it focuses on three questions. First, how prudent should spending levels be over a resource boom, considering the extreme uncertainty of future oil prices? Second, how should countries consider the range of spending options, as well as policies to diversify the economy? Third, what political economy and structural factors seem to have helped some developing countries to manage resource wealth better than others?

These questions are of course related. The more limited are spending options, the more will spending be constrained by capacity in particular areas, such as public investment planning and implementation. The choices actually available for a given country will also depend on its particular political economy. Some studies have offered complex model frameworks to solve for a set of saving/public-spending/transfer choices at each

\footnotetext{
${ }^{1}$ About 12 additional countries are heavily dependent on hard mineral exports. These share some of the challenges of hydrocarbon exporters, including concentrated and unstable resource income. However, hard mineral sectors often have deeper upstream and downstream linkages with the rest of the economy than hydrocarbons, and many countries have been able to take advantage of these to develop manufacturing capabilities.
} 
point in time in an optimizing framework (for example, Gelb 1990). Here we develop a simpler analysis that considers overall spending and composition of spending separately.

While oil represents wealth it also exposes exporting countries to great uncertainty. How cautious countries should be in spending depends on the symmetry of loss functions - the relative gains and losses from over-optimism and over-pessimism. Section 2 considers the spending choice using a simple framework that incorporates two plausible elements of macroeconomic asymmetry -- absorption constraints at high levels of spending, and asymmetric macro-adjustment in response to large positive and negative shocks. We have no clear calibration for the former which will depend on country conditions but can make plausible assumptions. For the latter, calibration is informed by several studies at macro and sector level. This framework offers some insight into the degree to which countries should depart from neutral expectations when planning to spend resource revenues. For credit-constrained exporters Van der Ploeg and Venables 2008 observe that domestic investments may have higher returns than foreign savings, and argue that optimal spending is higher than indicated by estimates of permanent income; we discuss the implications using the model.

Section 3 considers some of the options for using revenues, including transferring them to citizens in various ways, a topic which has been receiving increasing attention. These options, such as reducing non-oil taxes or providing subsidies or grants, involve tradeoffs among various possible goals: efficiency (minimizing deadweight losses), equity, sustainability, and whether they are likely to encourage greater domestic accountability. We also consider some country cases suggesting how oil wealth (or mineral rents more broadly) can be used to support economic diversification, a goal of many exporters but one rarely achieved.

This leads to the question of why some countries have done better in handling resource rents than others. The broad answer given is often "good governance", but can examples help us to be more specific? The set of developing countries that is both resource-rich and successful is depressingly small, but these better-performing cases, outlined in Section 4, suggest that several factors have been important. They include a strong political consensus on the need for stability, a strong and engaged technocracy, and interest groups able to act as agents of restraint on spending. There are no formulaic answers to the question of how to create these conditions, but the country cases suggest some possibilities and approaches as well as the role of particular constituencies in action as agents of restraint. Section 5 concludes.

\section{Spending Choices under Extreme Uncertainty.}

Hydrocarbon-rich countries represent an extreme within the range of resource-dependent countries. Rent is concentrated, linkages with other sectors tend to be modest and most exporters are heavily dependent on oil or gas for fiscal and export revenue. Bornhorst, Gupta and Thornton 2008 consider 30 countries over the period 1992-2005. During this period, a time when oil prices were mostly moderate or low in historical context, oil and gas revenues represented on average 16.2 percent of GDP or 49.1 percent of total fiscal 
revenue. For some regions the average was higher: for the 14 Middle East exporters, the averages were 20.0 percent and 57.2 percent respectively. But the true dependence of such countries is far larger than it appears, since GDP includes both the hydrocarbon sector and a range of other activities directly or indirectly dependent on the oil sector. Many non-oil taxes, such as import duties, are themselves dependent on activities and flows deriving from the hydrocarbon sector.

Even by the standards of volatile commodity prices, oil prices are exceptionally uncertain. Considering real oil prices over the period 1881-2007 (Figure 1), there has been little long-run trend but the coefficient of variation is 0.7 and the most recent cycle can only have increased this further.

Figure 1

\section{Long Run Oil Prices: 1881-2007}

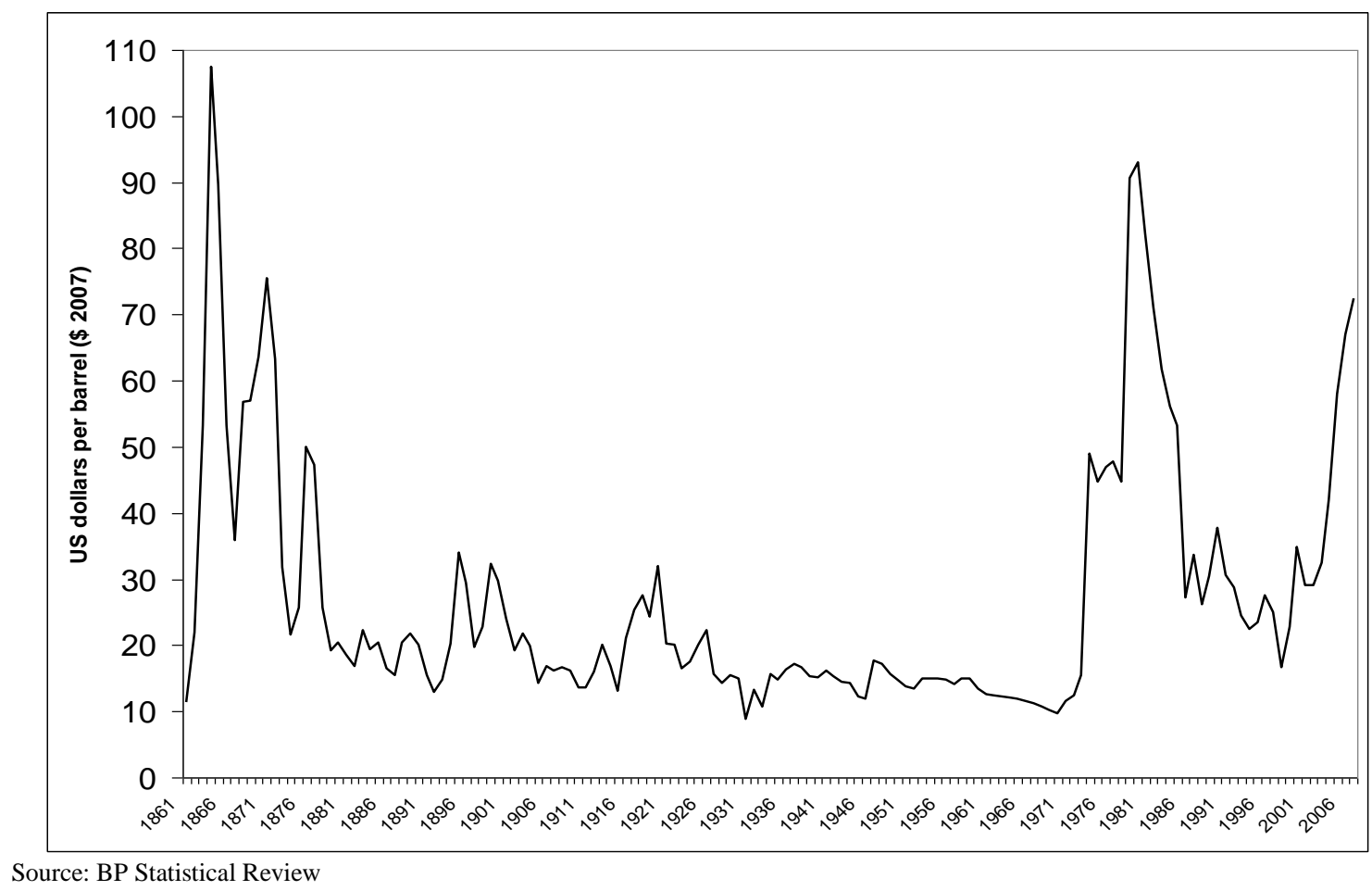

How well can we predict price trends? Past experience suggests very poorly. At least since the start of the 1970s none of the major turning points in the market has been widely predicted. Forecasts in 1981 made shortly before the price collapse wrongly projected sustained price increases; during the recent oil boom futures prices were flat, simply extending the current price out to future years (IMF 2007). While real prices cannot strictly conform to a random walk process because of some lower and some upper bound, estimated prediction models do little or no better than a random walk.

Hamilton 2008 provides a careful study of the statistical properties of oil price series. He finds that the random walk hypothesis cannot be rejected and that, starting from a price of $\$ 115$ per bbl, four years into the future we should not be too surprised to find the price of 
oil as high as $\$ 391$ per bbl or as low as $\$ 34$. The latter price was inconceivable at the time of his study (which was completed before the collapse) and far outside the range of observed futures prices. However, prices hit $\$ 34$ per bbl only a little later in 2008 . The resulting uncertainty is enormous for producers. Consider, for example, an exporter like Nigeria. With a base value of oil valued at $\$ 100$ per bbl, the difference in production valued at $\$ 50$ and $\$ 150$ is equivalent to a difference of 50 percent of GDP.

Oil exporters have typically not succeeded in smoothing these extreme price cycles. Table 1 shows the growth of oil exporting countries for which consistent data are available over the period 1965-2007, breaking out the period into booms and busts which coincide with spells of high and low oil prices. Over the 32 year period, the exporters grew more slowly than either middle-income countries or low-income countries, even though the definition of the latter group involves self-selection bias towards slow growth. Norway, a high-income exporter, escaped this fate; among the countries with data, Indonesia also did better than average. ${ }^{2}$

\section{Table 1}

Growth in GDP and Absorption per Head: Oil Exporting and Other Countries

\begin{tabular}{|c|c|c|c|c|c|c|}
\hline & $1965-72$ & $72-81$ & $81-90$ & $90-02$ & $02-07$ & $1972-2007$ \\
\hline & \multicolumn{6}{|c|}{$\begin{array}{l}\text { Growth Rates GDP/head } \\
\text { (Annual Average, Percent) }\end{array}$} \\
\hline Selected Oil Exporters* & 4.1 & 2.6 & -1.5 & 0.7 & 3.9 & 1.4 \\
\hline MICs & 3.5 & 3.0 & 1.7 & 2.6 & 6.1 & 2.8 \\
\hline LICs & 1.9 & 0.5 & 0.7 & 1.0 & 4.0 & 1.6 \\
\hline \multirow[t]{2}{*}{ Memo: Norway } & 3.2 & 4.0 & 2.6 & 3.1 & 2.1 & 2.9 \\
\hline & \multicolumn{6}{|c|}{$\begin{array}{c}\text { Growth Rates, Real Absorption/head } \\
\text { (Annual Average, Percent) }\end{array}$} \\
\hline Selected oil exporters** & 5.2 & 5.4 & -3.4 & 0.6 & 5.8 & 1.6 \\
\hline $\mathrm{MICs}$ & 2.8 & 4.0 & 0.9 & 2.5 & 5.9 & 2.8 \\
\hline LICs & -- & $0.5 * * *$ & 0.9 & 2.5 & 6.9 & 2.0 \\
\hline Memo: Norway & 4.5 & 4.4 & 1.4 & 3.0 & 4.4 & 3.0 \\
\hline $\begin{array}{l}\text { * Algeria, Cameroon, Ecuador } \\
\text { Venezuela } \\
\text { ** Algeria,Cameroon, Gabon, } \\
\text { *** Set equal to GDP growth }\end{array}$ & $\begin{array}{l}\text { abon, Indon } \\
\text { nesia, Iran } \\
53\end{array}$ & $\begin{array}{l}\text { sia, Iran, } 1 \\
\text { Syria,Trini }\end{array}$ & $\begin{array}{l}\text { eria, Sal } \\
\text { d and } T c\end{array}$ & $\begin{array}{l}\text { i Arabia, } \\
\text { ago, Ven }\end{array}$ & $\begin{array}{l}\text { ria, Trin } \\
\text { ela }\end{array}$ & Tobago, \\
\hline
\end{tabular}

Table 1 also confirms the tendency for oil exporters to alternate periods of shorter booms, marked by high but not spectacular growth rates of GDP, with prolonged slumps marked by stagnant or declining GDP. This supply-side pattern mirrors the even larger swings in the rhythm of real absorption, usually led by swings in public spending. For exporters

\footnotetext{
${ }^{2}$ Elbadawi and Kaltani (2007) find that over the period 1971-2005 GDP per head in oil exporting countries grew at about half the rate in non-oil-exporters.
} 
with consistent data, the average annual growth of real absorption per head swung from 5.4 percent in 1972-81 to -3.4 percent in 1981-90. For many countries, real absorption per head halved over this decade. Absorption per head was static over the subsequent decade and then boomed again at 5.8 percent as prices soared after 2002. Overall, as with GDP per head, it grew more slowly for the oil exporters than for other countries.

The destructiveness of these cycles is clear from many cases. Mexico borrowed against expectations of increasing real oil prices after 1981 and suffered badly when these expectations turned out to be far off track. Hausmann 2001 notes that between 1920 and 1980 Venezuela was one of the fastest-growing Latin American economies, with growth averaging 6.4 percent. But following several euphoric years after 1974 it experienced a sharp decline, with output per head halving over the next two decades. Nigeria offers a third example, with "voracious" spending increases outpacing revenue increases up to 1984, which was followed by sharply lower spending constrained by the previous buildup of huge debts (Budina and van Wijnbergen 2008).

Simulations with a multi-sector computable general equilibrium model indicate that optimal savings for a capital importing oil exporter during the 1973-81 boom would have been about $80 \%$ of incremental revenues (Gelb 1988). While some countries did save part of their windfall abroad (Indonesia) and some dis-saved heavily (Algeria, Nigeria), on average, the exporters saved little. Simulations also showed that the cost of overoptimistic spending during the boom years could be enormous for an oil exporter, easily turning the value of a windfall into a net loss. Many countries may have been more cautious in the recent boom than in the previous one but there is wide variation and some indication that countries with weaker governance were spending more aggressively, relative to their wealth windfall, than those with stronger institutions (IMF 2007).

Spending decisions by oil countries are often benchmarked on the permanent income approach, with the target primary non-oil deficit equal to the permanent income expected from oil savings and reserves. This benchmark, together with associated "stress testing" of spending policies against varying revenue projections, can provide a useful guide to prudent spending decisions, including the implications of reserve exhaustion. It does not, however, provide guidance on how spending plans need to take uncertain future revenues into account. Should expected future earnings be used in the calculation? Or should future earnings be discounted for risk, and if so how heavily?

In considering this question, it is important to factor in two types of economic constraints likely to be important in "boom-bust" scenarios -- constraints on the ability to productively absorb public spending when this increases to very high levels, and macroeconomic adjustment constraints in the face of positive and negative demand shocks. Both of these will "kink" the economy-wide supply curve in response to large swings in effective demand. Output falls more in response to demand slumps than it increases in response to demand booms.

Absorption constraints are often flagged in country-level analyses but we have no good estimates of how tightly they bind, in general, as spending rises. However, there is a strong presumption that the quality of public spending declines sharply when spending is 
ramped up to extreme levels, typically (from experience in the first oil boom) to levels on the order of 40-50\% of GDP. We can be more precise in estimating macroeconomic adjustment constraints, since a number of studies provide evidence on how supply curves kink in responses to large booms and busts. For the US economy, Cover 1992 finds that positive money-supply shocks have no effect on output whereas negative shocks do have an impact. For the Middle East, Kandil 1999 finds a similar result, with demand fluctuations leading to greater average inflation and lower average growth. ${ }^{3}$ Collier and Venables 2008 summarize research on the impact of large terms of trade gains and losses on developing countries. They abstract from the income effect accruing directly from changes in the terms of trade and find asymmetric adjustment: favorable shocks do not have significant effects on growth, but adverse shocks reduce output. For a typical African country, a terms of trade loss of 10 percent of GDP reduces growth in the following year by 3.6 percentage points. The implications of asymmetry are clear: underspending when prices are high can incur a small loss of welfare, but over-spending during a temporary boom can be costly, especially if financed by borrowing which will need to be repaid after the boom has ended, further constricting demand.

A Simple Model. A full analysis of spending decisions would need to take many country-specific issues into account. These include the time-profile of expected production and the probability of finding new reserves, options for spending (including investments, subsidies, and transfers to the population) the effectiveness of spending, and how fast this falls as levels rise, the costs imposed by sharp reductions in over-extended spending levels (investment wasted because of shortages of complementary recurrent resources) and the macro-economic costs of adjustment to sharp declines in demand, as well as the opportunity cost in terms of additional reserve accumulation and investment income foregone. ${ }^{4}$ Here we abstract from the issue of exhaustion and consider a very simple stylized model that focuses on only two effects: efficiency losses when public spending levels are very high and macroeconomic losses due to sharp cutbacks in the level of spending in response to falling income.

The model involves three periods: period 0 is pre-boom, and sets the historical base for public spending; period 1 is the boom, lasting N1 years and period 2 is the uncertain postboom future, lasting N2 years. The country faces an inter-temporal budget constraint: total spending over all years cannot exceed total revenue received. We assume a non-oil economy of 100 in each period and express oil income relative to this level. This therefore abstracts from population and non-oil GDP growth, and there is no secondperiod payoff to possible first-period investment. However, to partly compensate for this savings abroad yield no return either.

In a fully-specified model, the utility function would value a (possibly discounted) sum of annual utilities of consumption, but this would require setting out the detail of how oilled spending affects the entire macro-economy. In the simple reduced-form model used here (see also Engel and Valdés 2000), valuation is directly on "net" public spending,

\footnotetext{
${ }^{3}$ Reflecting macro level behavior, at a micro level Kandil (2006) also finds asymmetric responses for 28 two-digit Standard Industrial Classification (SIC) industries in the US.

${ }^{4}$ Many of these issues are considered by Engel and Valdés (2000). The model used by Gelb 1988 also incorporates some of these options, including the domestic pricing of energy over the boom-bust cycle.
} 
which allows for two types of efficiency losses. First, beyond a moderate level, the efficiency of spending begins to decline according to a quadratic function. We do not have good estimates of the parameters of such a cost function, which will depend on, among other factors, the quality of public sector management, investment programming and procurement. But as spending is accelerated beyond some very high level the marginal value of spending can reasonably be assumed to approach zero. On the basis of experience during the first oil boom, we set this level at $40 \%$ of non-oil GDP. ${ }^{5}$ Second, asymmetric adjustment is assumed, with losses due to sharp declines in spending. The estimates provided in Collier and Venables (2008) are used to calibrate the adjustment cost in the reduced-form model. Welfare is represented by the log of net spending to allow for diminishing marginal utility. The annual level is weighted in each period by the number of years to form the aggregate utility in each period.

What does such a model suggest about spending decisions during a boom when the postboom outlook is very uncertain? Since periods of high oil prices have typically been shorter than periods of low prices, we take N1 as 5 years and N2 as 20 years. We start from baseline revenue of 10 percent of non-oil GDP, a moderate level given the range of estimates in Bornhorst et al 2008. Spending is then optimized for two revenue profiles, a short boom, with oil revenues at 10, 30 and 10 percent of non-oil GDP in the pre-boom, boom and post-boom periods respectively, and a long boom, with the revenue profile 10 , 30 and 25 percent. Total spending is constrained to equal total income over the period ${ }^{6}$, and total welfare is the sum of its values in the first and second periods, with the second discounted in some simulations to reflect time preference.

Figure 2 shows the percentages of the maximum welfare achievable for each level of spending in Period 1 for each of the two revenue profiles. In the case of the short boom and with no discounting, the optimum is to spend 14 out of the 30 during the boom years; this is just under half percent of total oil income or 20 percent of incremental oil revenues.(or) The rest will be saved abroad, to be spent in the second period. For the long boom, it is optimal to spend about $85 \%$ of total oil revenues or 80 percent of incremental revenue. But the losses due to misjudging the nature of the boom are highly asymmetric. Slow initial spending results in only a small loss of the potential value of the long boom; the payoff function is very flat. In the opposite case of a short boom, overoptimistic initial spending results in the loss of most of the potential value. . Table 2 summarizes the payoff to optimized plans based on correct and mistaken predictions. Over-optimism (mistakenly expecting a long boom) yields a huge loss, equivalent to $32 \%$ of the maximum gain over a short boom. ${ }^{7}$

\footnotetext{
${ }^{5}$ Rapidly growing economies normally benefit from a high investment rate in the range of 30-40\% of GDP but few have sustained rates of over $40 \%$ for extended periods.

${ }^{6}$ This implies a downward bias for the estimate of optimal savings if absorptive capacity is a severe constraint over the period as a whole or if declining oil reserves reduce expected long-run permanent income after the 25 -year period. In both of these cases the appropriate response will be to save more abroad than indicated by the model.

${ }^{7}$ The loss would be even more worse if spending were further boosted by borrowing during the boom, expecting it to be long-term.
} 
If each scenario is expected with a probability of 0.5 , the expected welfare-maximizing spending level, at about 22 percent of incremental boom income, is therefore only a little higher than the optimal spending level for the short boom.

After several years of high prices optimal savings abroad would cumulate to some 80 percent of GDP for the stylized exporter.

Figure 2

Percentage of Maximum Windfall Gain: Short Boom and Long Boom

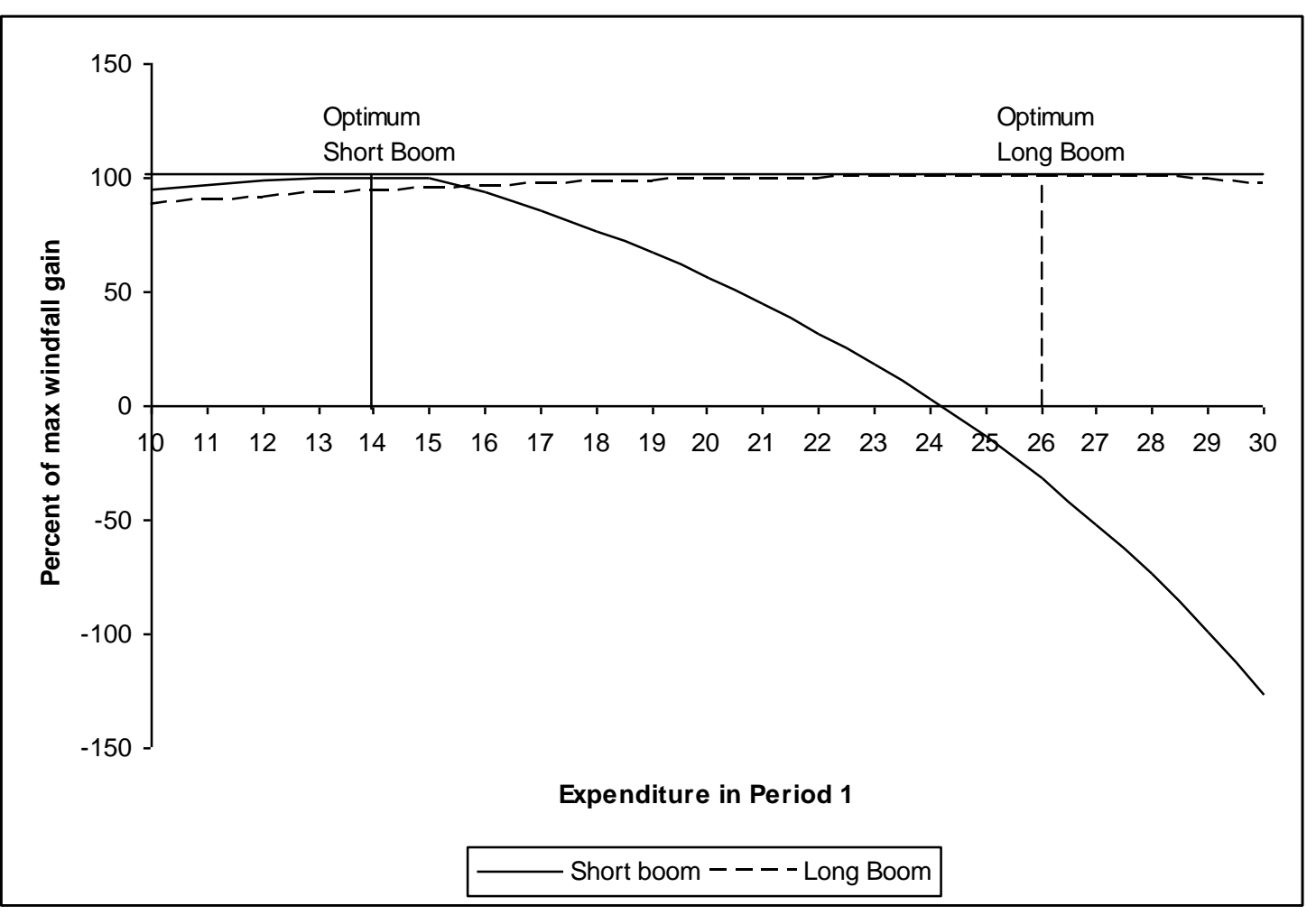

Table 2

Payoff Matrix:

Percentage of Maximum Windfall Gain

Short versus Long Boom: Expectations and Reality

\begin{tabular}{|c|c|c|c|}
\hline & & \multicolumn{2}{|c|}{ Reality } \\
\hline & & Short boom & Long boom \\
\hline Expectation & Short boom & $100 \%$ & $94 \%$ \\
\hline & Long boom & $-32 \%$ & $100 \%$ \\
\hline
\end{tabular}

Source: Model Simulations

Spending decisions are inherently political, however. Governments may have a short horizon, and discount future welfare. Using a discount rate of 10 percent per year somewhat increases "optimal" period 1 spending, but the heavy weight of the long, post- 
boom period in total welfare means that moderate levels of discounting are not likely in themselves to lead the economy into a serious problem. Only when the political horizon is very short (discount rates approaching 30 percent, or an effective horizon of 1-3 years) will period 1 spending rise towards the level of revenues.

More problematic is the possibility that policymakers might simply not factor absorption constraints and macroeconomic adjustment costs into their spending decisions. There can be many reasons for this. When budget discipline is weak, the congestion costs from synchronized spending will be external to an individual decision-maker. Corrupt officials may value contracts for their potential to generate bribes rather than effectiveness; they pocket the gains from over-spending while the losses are diffused across the economy. Policymakers may also not believe that macro-adjustment costs will bind if spending declines sharply, perhaps because (against all the historical evidence of oil booms) they expect high investments in the boom period to pull the economy through any post-boom demand slump.

The combination of such factors with a degree of political discounting or over-optimistic projections of oil incomes is disastrous. In the first period the government spends heavily. This results in a catastrophic contraction in the second period and turns the potential windfall into a sizeable loss (Figure 3). This stresses the importance of disseminating the experience of other countries, as well as identifying strengthening constituencies and possible institutional arrangements to sustain cautious spending.

Figure 3

Percentage of Maximum Windfall Gain: Discounting, and Ignoring Adjustment Costs

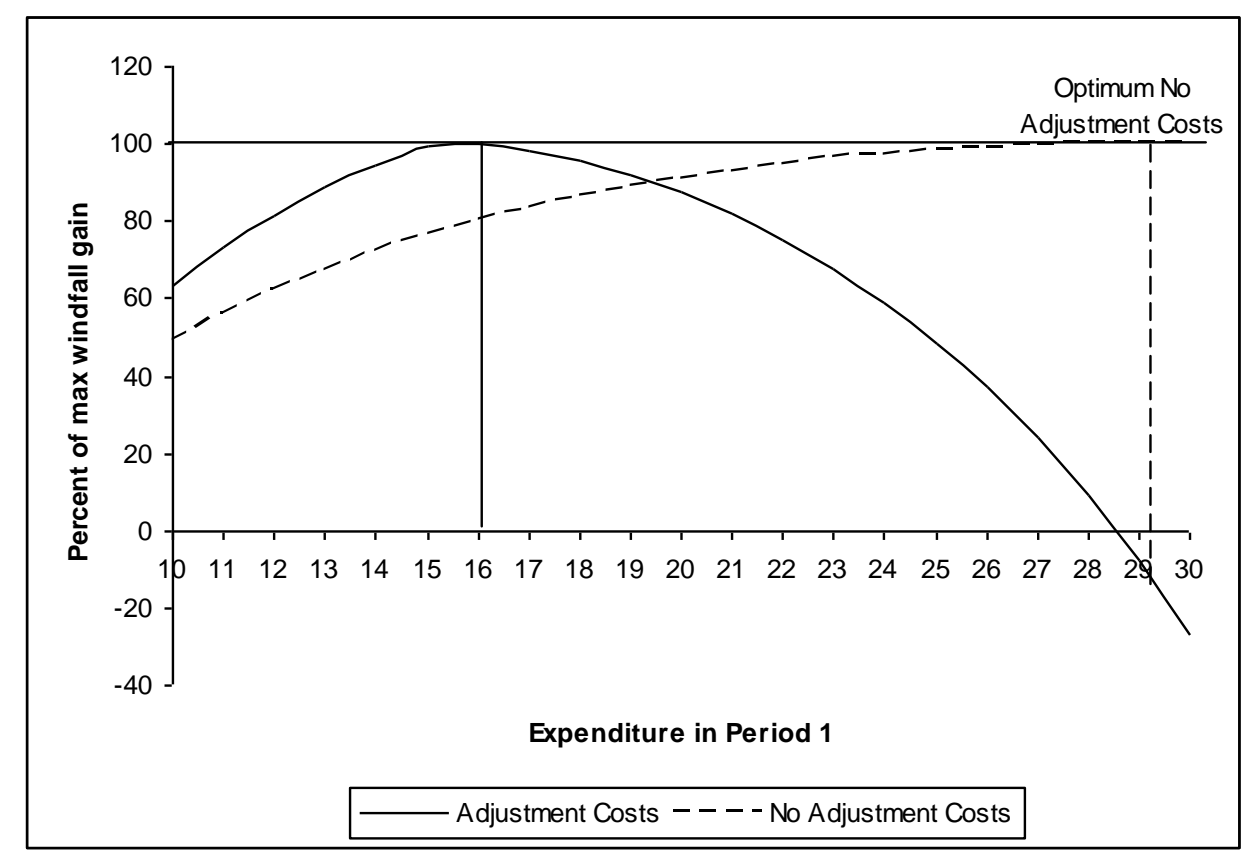

Source: Model Simulations 
As noted by van der Ploeg and Venables 2009, consumption-smoothing guidelines based on permanent income ignore some essential features of developing economies. Many are capital scarce, have high costs of financial intermediation, and face credit constraints in international capital markets. The rate of return on domestic spending may be higher than the returns to saving abroad, even if lower than borrowing costs. With binding credit constraints it will be optimal to shift spending towards earlier periods in the event of a resource discovery or boom. With small windfalls, the economy's growth path is accelerated, but no sovereign wealth funds are built up; only if windfalls are large relative to initial debt will it be optimal to save abroad and budget for an associated permanent increase in consumption.

Bringing in absorption inefficiencies at high levels of expenditure and asymmetric macroeconomic adjustment does not change the logic of this analysis, but constrains its applicability. In the model without these constraints, a premium of 10 percent ( 5 percent) on domestic spending during the boom period increases its optimal level by 64 percent (21 percent). However, when absorption and macroeconomic constraints are applied, the credit constraint has only a modest impact, about a 7 percent increase in first-period spending (Figure 4). This suggests that credit constraints should be factored in more strongly for modest resource discoveries and windfalls, rather than major ones where spending heavily is likely to cause the economy to run up against these other constraints. 
Figure 4

Percentage of Maximum Windfall Gains:

Credit Constraints and Adjustment Costs

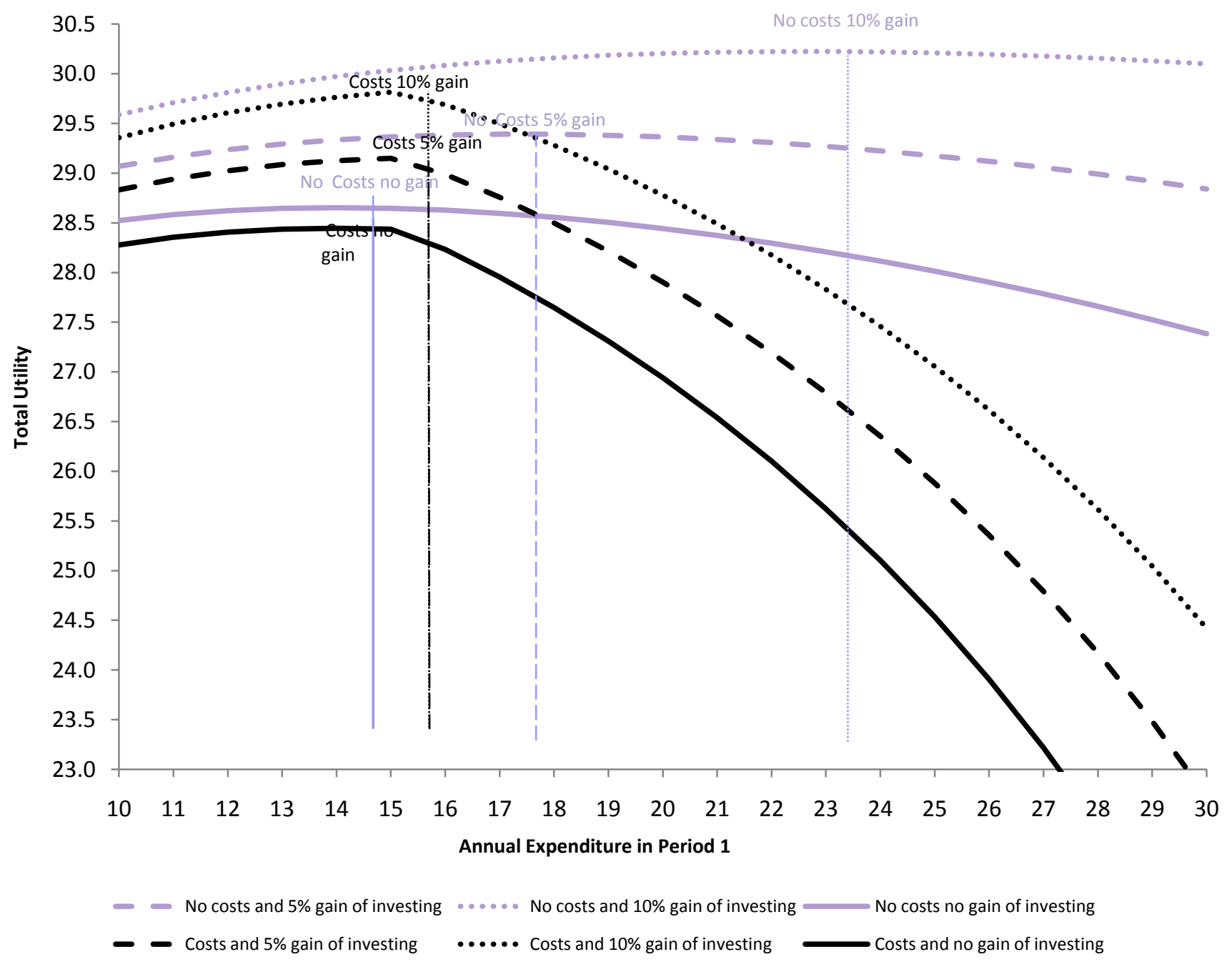

Even though futures and options to hedge commodity price risk offer potential efficiency gains relative to sovereign wealth funds $(\mathrm{SWFs})^{8}$, resource exporters have been surprisingly sparing in their use of these instruments. Rietveld and Pringle (2007) identify 23 major funds for managing sovereign wealth, of which 14 are owned by oil

\footnotetext{
${ }^{8}$ SWFs are able to act as a buffer only once they have been accumulated, whereas options can insure producers against price risk at any stage in the cycle.
} 
exporters. Funds can offer several potential contributions, including improving transparency, widening accountability mechanisms to include diverse interest groups, including citizens directly as in Alaska where the fund was designed "to be saved from the ravages of mendacious politicians" (Cowper 2007). Because of the length of the oil price cycle, even funds set aside to smooth booms and busts (rather than to defend against resource depletion) will need to cumulate to substantial levels, sometimes to greater than GDP, and to be managed with a multi-year horizon. As in Botswana, the prospect of higher returns on a transparently managed reserve fund can help justify saving and insulate wealth management from politics, even if the fund is not a "lock box" with formal withdrawal rules. Funds can also be linked to more tangible objectives to increase public understanding of the need to save. In Chile, the objective of paying down public debt was important in sustaining adherence to fiscal rules; in Norway, the prospect of escalating pension and health payments to an ageing population was cited to justify the petroleum fund. ${ }^{9}$ In developing countries with youthful populations, funds could be set up to guarantee the future education of all citizens.

Nevertheless, a wide range of studies finds that resource funds are neither necessary nor sufficient to sustain good macroeconomic management in volatile mineral economies (Davis et al 2003). When the institutional environment is weak funds can be subverted, through rule changes, expropriation, or borrowing against the saving of the fund, as for example in Venezuela (Eifert et al, 2003). In particular, as shown most recently by the case of Chad, the formal mechanisms of a fund cannot substitute for the absence of effective domestic checks and balances on the government. An analysis of the impact of oil funds and fiscal rules on the fiscal responses of oil producing countries to the most recent oil boom found that they did not have a significant impact; in contrast broader governance institutions did appear to have an impact (IMF, 2007).

\section{Options for Using Resource Rents.}

\section{3a Transferring rents to citizens.}

In addition to increasing public investment or recurrent spending to provide public goods, oil exporters have a wide range of options for distributing rents among their citizens. Indeed, since citizens "own" the oil resources in the first place ${ }^{10}$, it is sometimes argued that the most appropriate approach is to transfer them back in some way, whether in the form of lower non-oil taxes, price, employment or investment subsidies, or direct transfers. Can rents usefully be transferred to citizens, whether directly or in other ways, and what are the tradeoffs?

\footnotetext{
${ }^{9}$ In 2006 the Government Petroleum Fund changed name and it is now called the Government Pension Fund.

${ }^{10}$ At least that part of the resources that are not owned by foreign companies; for further discussion, see Stiglitz 2006. The precise meaning of citizen ownership is often unclear, for example, whether it includes future citizens or only current citizens, or whether citizens in producing regions should be particularly favored.
} 
Most exporters do distribute a share of their oil rents to citizens, but they do so in indirect ways. One prevalent policy is to reduce non-oil taxation relative to levels in other countries. Bornhorst et al 2008, find that on average 1\% of GDP in oil taxes is reflected in $0.2 \%$ lower non-oil taxes. The average tax relief for the 30 exporters identified in that study would then be $3.2 \%$ of GDP.

On the positive side, a lower tax burden might be expected to reduce the deadweight costs of taxation if the quality of tax administration does not decline at the same time. A low-tax environment could also be a useful part of a strategy for improving the business climate and encouraging investments to diversify the non-oil economy, to compensate for the adverse effect on profitability of an exchange rate boosted by oil exports. On the negative side, it is argued that the need for a state to tax its citizens has been an essential component of the process of state-building, both for developing state capabilities and for encouraging demand for public accountability (Brautigam, Fjeldstad and Moore 2008, ). In Latin America and Africa, well governed countries such as Costa Rica and Mauritius suggest that taxation is one of the main ingredients to an accountable and effective state (OECD 2008). These benefits could serve as an offset to the deadweight costs of taxation, but there has not yet been a systematic comparison between them. Sooner or later most oil exporting countries will need to turn to their non-oil tax systems to finance spending programs, so that a low-tax period should be used as an investment to improve administration, encourage compliance and broaden the tax base. But few countries follow this path; while non-resource tax yields in resource-rich countries are certainly lower, estimates of the quality of non-resource tax administration suggest that it is typically worse (Knack 2008). Least prudent is perhaps Alaska's approach of eliminating state sales and income taxes rather than just lowering rates and broadening the base. ${ }^{11}$

A second widely-used approach is to subsidize domestic prices for petroleum derivatives, other energy and sometimes other essentials to far below world market levels. Many producing countries hold petroleum prices to far below market levels, incurring implicit fiscal costs equivalent to several percent of GDP. In the short run, containing domestic price spikes can be an understandable response to a sharp rise in world prices; there is little point in subjecting the economy to a supply shock and at the same time tempting fiscal expansion by further boosting swollen public coffers. However, this option does not provide for a transparent linkage between the levels of rents and transfers.

Consumption grows even in the face of high world oil prices, which further destabilizes prices for the portion of oil traded on free markets. The fiscal costs can be substantial, on the order of several percentage points of GDP. Cheap energy policies tend to be regressive, inefficient and difficult to reverse; spiraling domestic demand (including

\footnotetext{
${ }^{11}$ Public opinion strongly supports the Permanent Fund's dividend program and the dismal record of efforts to gain public support for tapping the Fund to help finance deficits in the general fund suggests that, at least up to now, Alaska's voters believe that the marginal value of private goods exceeds that of public goods. On the other hand, Alaska's ratio of Federal receipts to taxes has been one of the highest in the US, at $\$ 1.87$ received per \$1 paid in 2004 (Taxfoundation 2006, Federal Taxes and Expenditures by State, March).
} 
demand inflated by smuggling) and resistance to adjusting prices, even to inflation, often makes them fiscally unsustainable. ${ }^{12}$

A third approach, more widely used in the Middle East than elsewhere, involves expanded levels of public employment for nationals. At the turn of the century, public sector jobs represented around 80 percent of employment in the oil-rich countries of the Gulf (World Bank 2004). In Kuwait, for example, employment for nationals is virtually guaranteed, together with a wide range of benefits including housing loans, marriage bonuses and retirement income.

Few, if any, developing oil exporters look to direct distribution as pioneered by Alaska, but there is increasing interest in this option as the shortcomings of other approaches become more apparent. Direct transfers to citizens, or citizen groups, can be provided in many ways. Community-based programs can offer one way to distribute oil rents effectively and create a constituency with an interest in their effective management (Moreen 2007). Such programs have been used effectively on a large scale in Indonesia where INPRES programs absorbed almost one fifth of domestically funded development spending, providing low-wage rural employment in construction projects. Similar projects at the village level provided only materials, requiring the communities to contribute unpaid labor. Together these projects created some 1.5 million person-years of employment in the early 1980s, equivalent to almost 3 percent of the labor force.

The experience of other developing countries suggests that direct transfer programs can also be used to distribute rents on an individual basis. Conditional cash transfer schemes have increased their prominence after their piloting in Mexico's Progresa program and Brazil's Bolsa Família; they are now being implemented in at least 14 developing countries and, most recently, in New York City. They provide payments to poor families conditional on specified child behavior, such as attending school or receiving essential health services, including vaccinations. While the outcomes of these transfer systems depend on their design and country conditions, ongoing impact evaluations suggest that they can be an effective way to improve living conditions and widen access to a range of services (Behrman, Sengupta and Todd, 2005; Soares, Ribas and Osório, 2007; Fiszbein and Schady 2009). South Africa offers a different model, with pensions, disability and child support grants that amount to some 3.5 percent of GDP and account for two-thirds of total income for the poorest quintile of the population. Careful evaluation suggests that, if appropriately implemented, such targeted grants can have a positive impact even if not conditional. ${ }^{13}$ Moreover, recent research by Baird, McIntosh and Ozler 2010 suggests that that poor people will usually use extra income effectively and that conditionality may not be central to obtaining favorable development outcomes from grant programs.

\footnotetext{
${ }^{12}$ Cheap fuel policies also impact on environmental sustainability and encourage reserve depletion. Countries that have considered replacing other subsidies by an across-the-board transfer system to households include Iran and Mongolia.

13 The CSG is targeted to "follow the child" and is received almost exclusively by women, as the primary caregivers. The projected gain in lifetime earnings of the children receiving the grant significantly exceed the costs (Agüero, Carter and Woolard, 2007). Such programs could be carefully considered by cash-rich oil exporting countries with widespread poverty and modest capacity to implement conventional programs.
} 
Resource rents are generally considered to be the property of all citizens, so that it is not clear why distribution should be either be conditional or targeted. A number of recent papers have argued that countries - including Iraq - should adopt direct distribution plans (see, for example, Birdsall and Subramanian 2004, Palley 2003, Sandbu 2006, Moss and Young 2009). A more equal distribution of natural resources could promote structural change and economic growth, facilitating investments by credit-constrained individuals and shifting the distribution away from a political elite of resource appropriators towards entrepreneurs, resulting in economic policies and institutions that are more conducive to productivity gains (Falkinger and Grossmann, 2005). Direct, universal transfers would reduce one set of deadweight losses associated with price subsidies and could increase government accountability by giving citizens a direct interest in the amount of oil revenues channeled into the budget. "Giving away the rents" and taxing it back would also eliminate potential governance losses due to a lower need to tax citizens.

There is still the question of whether direct transfers on a large scale would discourage labor supply and weaken the incentive to upgrade skills. Evidence on the impact of welfare and transfer programs on labor supply is limited and mostly confined to industrial countries, though the range of evidence for developing countries is growing. One general conclusion is that leisure is a normal good; studies assessing the Aid to Families with Dependent Children (AFDC) program concluded that it reduced labor supply by from 10 percent to 50 percent (Moffitt 2002). A survey of several studies found an average income elasticity of -0.10 for prime male labor supply and one of -0.28 for female labor supply. ${ }^{14}$ Wage elasticities which combined the negative income effect and positive substitution effect, were sometimes negative and sometimes positive.

For developing countries, there is some evidence that labor supply curves are backwardsloping, particularly for women and at low income levels (El-Hamidi 2003). SalehiIsfahani 2002 suggests that at the margin the availability of oil income in Iran reduced the return to work and human capital and thereby discouraged fertility decline and greater investment in children. However, grants can also free up constraints that limit the ability of the poor to participate in productive activities. Woolard and Leibbrandt 2010 find that South Africa's extensive grant system enables migration in search of employment; even if they may reduce incentives for working-age household members to look for work the overall effect may be positive. Ross 2008 argues that the availability of oil income reduces female labor-force participation in exporting countries by crowding out low income wage labor, but this comes largely from eliminating the demand side from laborintensive sectors, such as textiles and clothing.

Any large universal transfer system, such as those which can be made by countries with small populations and high oil incomes, will probably need to be complemented by a package of measures to encourage skills upgrading and labor force participation. This could include generous education and training supplements, and state funding of payroll taxes for citizen employees. Countries with adequate fiscal resources could also consider

\footnotetext{
${ }^{14}$ The higher elasticity for females might be due to the financial benefit of dispensing with child care once income is sufficient for females to withdraw from the labor force.
} 
an income subsidy, possibly with payments actually increasing with earned income up to a generous level to encourage skills upgrading.

Whatever their precise design, institutional conditions will affect whether transfer programs are effective and at what level of decentralization they can be made. Since transfers tend to shade into entitlements over time and household and sub-national budgets face great difficulties in adjusting to very large income shocks, stabilizing public transfers over time seems essential. Programs need to embody design elements that reduce the prospect of capture by local elites (Platteau 2004); if not direct distribution to individuals, these can include transparent reporting on allocations made and received, monitoring the uses of funds, or allocating some communal resources to traditionally less powerful groups, such as women. ${ }^{15}$ New technology, including biometric identification and cell-phone payments systems, could also be used by some exporters to transfer oil rents to citizens more efficiently. ${ }^{16}$ Distributing rents to citizens and communities will not provide a panacea to all of the problems plaguing oil countries. However, some degree of direct or community-level distribution could be useful in reducing the buildup of large ineffective central programs and in widening access to resources and building human capital. If transparently linked to resource rents and spending, they may also help build a constituency for good governance.

\section{3b. Encouraging economic diversification.}

"Sowing the oil" to diversify the non-oil economy has been an objective for many oil exporters, but only a few resource-rich countries have succeeded in diversifying their economies. Coxhead 2007 identifies five high-performing resource-rich countries Malaysia, Chile, Indonesia, and Sri Lanka and Thailand (the latter not being mineraldependent). All have diversified towards manufactured exports or, as in Chile, have widened their range of resource-based exports to include new and more sophisticated products. In other cases, resource-rich countries seem to have been slower to diversify. Auty 1990 found that industries tended to be more heavily protected in resource rich countries, and that they take longer to mature and "grow up". 17

\footnotetext{
15 Transparent transfer programs can also be a cost-efficient way of overcoming systemic leakage of funds in service delivery. For example, in Uganda tracking surveys made in 1996 showed that local bureaucrats were capturing $80 \%$ of non-wage education spending. After an information campaign, both nationally and at the district and school level, a repeat survey showed that schools now received over 90 percent of their allocations. This remarkable improvement was achieved through government's efforts to disseminate information both through the media and systematically by posting public spending information at schools (Reinikka 2001).

${ }^{16}$ Many countries are currently implementing or planning to adopt biometric documentation ( digital fingerprinting and iris recognition) for security and other reasons. South Africa has implemented the world's largest biometric identification system, the Home Affairs National Identity System (HANIS), covering some 43 million citizens. Systems of this type are increasingly being used to implement transfer programs more effectively in countries such as South Africa, India and Malawi.

${ }^{17}$ A particular risk for large "mega-project" investments is the conflict of interest that can arise when a private partner with a small equity stake in a largely public project is also a major contractor or supplier. Profits from cost overruns can then more than compensate for equity losses. This creates incentives for over-optimistic feasibility studies and for downplaying the risks, with potentially huge losses for the government (Gelb 1988).
} 
Diversification requires a combination of three policies - a reasonable level of macroeconomic stability underpinned by prudent spending, a reasonably open trade policy, and the active use of resource rents to increase the productivity of other exportable sectors and reduce their production costs, whether by funding infrastructure, temporary subsidies or other methods. All of these are vital. Even in well-managed countries, appreciating real exchange rates can pull factors of production away from other export sectors; closing off the flow of imports will only result in higher prices for all domestic goods and services and less competitive conditions. Boom-bust cycles compound the problem by increasing price risk, further discouraging investments in sectors producing tradeables and encouraging premature specialization in resource sectors and still more volatile economies (Hausmann and Rigobon 2003).

Moving beyond macroeconomic policies, several countries offer lessons on diversification strategy. Malaysia was fortunate in having a rather diversified resource endowment, including rubber and tin, as well as forest products, which preceded oil as export staples. It sustained a high and relatively stable savings rate, and implemented land development and replanting schemes to expand and modernize the production of rubber and palm oil. It also undertook heavy investments in technology and infrastructure, especially energy, communications and transport, leading to rapid industrial transformation. Although Malaysia did start out on a protectionist path in the 1960s, it maintained a relatively open trade regime, with domestic investments aimed at reducing production costs and increasing competitiveness.

Chile offers several examples of successful active public policies to help develop highvalue industries, including salmon, wine and horticulture. These included encouraging technical development and adaptation, disseminating information on standards, providing infrastructure and information and coordinating numerous small producers (Benavente, 2006 and Katz, 2006). Both of these cases involved developing long-term public-private partnerships such as those involving CORFO and Fundación Chile to help producers achieve critical mass and capabilities. Chile's successful counter-cyclical macroeconomic policies, discussed further below, also played a central role in stabilizing incentives for non-copper exporting industries.

Indonesia offers an interesting example of a low-income country's efforts to use its hydrocarbon resources to support agriculture. Good luck played a part in this success, which would not have been possible without the development of disease-resistant and high-yield rice varieties. But their diffusion in the 1970s and 1980s would not have been possible without the unusually broad-based development policies followed by the government, including the use of oil income to develop natural gas resources, both for export to Japan and as an input to fertilizer production. Fertilizer was then distributed at subsidized prices, greatly boosting yields. In addition, public spending was moderated flexibly in response to oil booms and busts, including restraining actual spending through administrative controls to below budgeted levels at the height of the first oil boom (Gelb 1988). These measures, as well as devaluations in 1978, 1983 and 1986, prevented the real exchange rate from moving too far out of line, so limiting the adverse impact on 
agriculture and other non-oil traded sectors, and encouraging diverse exports including manufactures $^{18}$.

Do such examples have lessons for other resource-rich countries? Clearly, the potential for diversification is affected by many factors, including the resource base, the capacities of the population and the quality of governance. Some countries, such as Botswana (which was not a major diamond exporter at the time of the baseline for Coxhead's study), score highly in many dimensions, but face particular geographical, ecological and skill constraints that make competitive diversification difficult to achieve. ${ }^{19}$ Yet many countries do have diverse resource bases and a range of potential alternatives, so that the tradeoff between spending to boost consumption in the shorter-term and investments to diversify and sustain growth in the longer-term is favorable to the latter. The examples above suggest that diversification outside the dominant resource sector is not impossible.

\section{Common Features of Good Performers}

Where is the starting-point for good policies? Can this only come from a legacy of strong institutions, or is it possible for countries to break free of the path dependence associated with poor initial institutions? (Heinmiller, 2009) Countries such as Norway or Botswana that started off from strong institutional conditions can clearly expect to have a more positive range of alternatives for using oil rent than extremely institutionally challenged countries, such as Chad or Equatorial Guinea. ${ }^{20}$ However countries such as Chile, Indonesia and Malaysia show that even resource-rich countries with a history of instability and fractious politics can experience windows of opportunity for good management.

Botswana is perhaps the most striking case of an initially poor mineral exporter with strong initial institutions. Acemoglu, Johnson and Robinson (2003) suggest that the foundation was laid before the discovery of diamonds. Inclusive traditional institution placed constraints on political elites and there was minimal disruption to these traditions by colonial rule; powerful cattle-based rural constituencies had an interest in protecting property rights; post-independence political leaders were also willing to place national interest above tribal interests. Particularly noteworthy was Seretse Khama's initiative in assigning sub-soil mining rights away from the tribes and towards the state, in this way heading off tribal contestation for revenue and cementing a common national interest.

Botswana then used its diamond income well to further strengthen institutions and capacity. It remunerated civil servants adequately and employed a corps of long-term

\footnotetext{
18 Together with spending restraint, the devaluations of 1978, 1983 and 1896 resulted in a 50\% adjustment of the real exchange rate.

${ }^{19}$ Despite a generally good investment climate, Botswana's industrial sector appears to be less competitive than those of other middle income countries, World Bank 2007.

${ }^{20}$ Equatorial Guinea has been cited as an extreme case where oil rents sustain a pathology of authoritarian rule, instability and underdevelopment, from which it is difficult to exit. McSharry 2006 analyses the political economy of oil in Equatorial Guinea, suggesting that the extraordinary weakness of government institutions and the dearth of social programs make it less likely that the government will be able to buy the acquiescence of the population in the same way as, for example, Kuwait or Saudi Arabia.
} 
foreign advisors to work alongside domestic officials, rather than rapidly indigenizing the civil service and lowering its quality. More recently, the government sought and obtained a sovereign debt rating even though Botswana had no immediate need to borrow. The rating was seen as a commitment device, to alert citizens by signaling potential policy slippage by future governments.

The experiences of Chile, Malaysia and Indonesia (at least during the first decade of the Suharto government) suggest a number of common elements that can support good management. Considering first Chile, the state has long been considered as generally capable, and technical economic capacity, including in key ministries and Central Bank, has traditionally been strong. In the early 1970s the country suffered both serious macroeconomic instability and social polarization. The period after the 1970 election of the Allende government and the September 1973 Pinochet coup was particularly traumatic; in 1973-75 the consumer price index rose by 3000 percent; this was followed by a deep debt crisis and economic contraction in the early 1980s. Unemployment levels reached 33 percent by 1982. Following the return of civilian rule in 1990, the traumatic experiences of the two previous decades underpinned widespread consensus around preventing further disruptive boom-bust crises and avoiding conditions that might precipitate the political instability that could lead to a return to military government. The result was a broad constituency in favor of both economic stability and public debt reduction. The strength of this consensus is demonstrated by Chile's response to spiraling copper prices and the exceptional accumulation of surpluses in its copper stabilization fund after 2005. Net public debt was reduced to minus 14 percent of GDP by 2008. Nevertheless, sustaining these policies has required continuous efforts by the technocracy to reach out to elected officials, to explain the implications of over-spending, and to enlist the non-copper export sectors, which are important employers, in support of cautious policies.

Indonesia offers another interesting example of cautious and flexible macroeconomic management -- implemented without a dedicated fund, without transparency, and even in violation of a balanced-budget fiscal rule -- at least during the first part of the Suharto period. This phase was classified as an example of "reforming autocracy" by Eifert et al (2003). As in post-Pinochet Chile, the Suharto government came into power with a huge stake in stability. The last years of the "Guided Democracy" of the Sukarno period had been increasingly chaotic, including rice riots and ethnic rioting. The 1975 crisis of Pertamina, the national oil company, reinforced the caution of the government, and added to the credibility of the technocrats - a very stable team of economic advisers widely known as the "Berkeley Mafia"21. This team proved to have both great permanence and leeway to shape policies. Through the oil booms of 1974-81, the government formally adhered to a balanced budget law. However, without disclosure to the public or the parliament, bureaucratic controls were applied to slow actual spending, creating a de facto surplus and doubling reserves. Indonesia also managed its spending programs with great flexibility. As oil prices fell after 1981, the government moved aggressively with a drastic re-programming of its development spending, cancelling projects, cutting

\footnotetext{
${ }^{21}$ Pertamina had been under the management of a military associate of the President, so that its 1975 crisis - which required a $\$ 1$ billion bailout - strengthened the hand of the technocrats.
} 
subsidies and spending, as well as stabilizing the real exchange rate through progressive devaluation.

Malaysia, another success case, faced a threat to economic and social stability from either of two paths: rapid growth with Malays politically dominant yet economically

disempowered, or economic collapse caused by excessively redistributive policies. These threats were clearly recognized. Neither of these options was attractive, leaving effective economic management and the reinvestment of rents to encourage growth, especially employment-creating growth for Malays, as the only option (Abidin 2001; Rasiah 2006).

Chile, Indonesia and Malaysia are clearly very different cases, yet they show some common features, which are also shared by Botswana and Norway.

First, two goals were seen as important -- accelerating development and sustaining economic and social stability. These goals enjoyed a fairly broad basis of support in all of the countries.

Second, the governments concerned were able to draw on a strong and credible technocracy, with a good understanding of the risks inherent in a minerals-based development strategy. Close relationships between politicians and technocrats helped to keep these issues at the forefront of policy.

Third, constituencies rooted in non-oil tradable sectors were influential in all of the countries. In Botswana, these were the traditional chiefs and cattle owners. In Malaysia tin and rubber producers were influential. Agriculture played a similar strategic role in Indonesia, because of its importance in sustaining rural incomes and social stability. Similarly, in Norway, fishing and other decentralized industries supported cautious spending policies. In Chile a range of resource-based commodity exporters had developed over the years of low copper prices into substantial employers. They were courted by the technocracy and were rolled out as strong advocates for restraint during the copper boom. These interests have been important forces for stability; they have helped to restrain sharp exchange rate appreciations that would damage the sectors concerned.

Nigeria's recent economic reforms offer further insights into the factors that can stimulate reforms, including the importance of domestic ownership. Contrasting Nigeria and Indonesia, Lewis (2007) notes the importance of social divisions, distinct institutional interests and competitive patronage in preventing successive Nigerian regimes from providing consistent, credible signals to private investors. This also resulted in the creation of a diffuse, rent-seeking business class. But dismal economic performance had come in for mounting popular criticism. During the first democratic government of President Obasanjo, initial intentions of economic reform withered in a political quagmire, and the political goodwill gained by the democratic government had not proven sufficient to secure debt relief from Nigeria's creditors, which was an important objective. There was a growing concern that two democratic terms might conclude without leaving behind a significant positive legacy. A small team of able technocrats was installed after Obasanjo's re-election, and given strong backing for an unprecedented 
program (Okonjo-Iweala and Osafo-Kwako 2007). Macroeconomic, budgetary and fiscal management were rapidly strengthened and due process mechanisms were instituted to increase the value for money of public procurement. Fiscal transparency and accountability was also promoted, including the publication of accounts and the disclosure of fiscal transfers made to sub-national governments. Reform momentum was sustained in various ways, including the development of national and state-level development plans.

The Bretton Woods Institutions were conspicuously absent from these home-grown processes, which were designed to emphasize domestic ownership and help develop a national consensus. To sustain domestic support for reforms, Nigeria resisted creditors' desires for a formal IMF program. The outcome was the development and first application of the Policy Support Instrument (PSI), to support low-income countries that did not want IMF financial assistance but rather the Fund's seal of endorsement of good management, to be provided to creditors and donors, multilateral development banks and financial markets. It is too early to forecast the eventual result of the reforms, but fully reversing them will not be easy.

\section{Conclusion}

This paper has considered three basic questions facing oil-rich countries. First, how cautious should they be in response to great uncertainty over future prices? Second, how should countries consider the use of rents, including for the possible purpose of economic diversification? Third, what factors have helped some countries to do better, both in stabilizing aggregate demand over the cycle and in terms of making more effective spending decisions? Full answers to such questions will only emerge from a countryby-country analysis, and with the recognition that decisions on aggregate saving and spending and on the composition of spending are parts of the same optimizing problem. However, it is useful to consider the decisions separately and also to look at country experience, not for rigid formulae and prescriptions but to help inform thinking in particular cases.

Consider first aggregate saving versus spending. Oil dependence exposes exporting economies to enormous levels of uncertainty and potentially to extreme macroeconomic instability. The penalty function of getting spending wrong is heavily asymmetric: the loss from under-spending is modest, that from over-spending is potentially very large, even more than the maximum potential benefit of a windfall. A simple stylized model incorporating absorption constraints and macroeconomic adjustment costs confirms the benefits of caution: from a stabilization perspective, even with a 50-50 chance that high prices will continue, the stylized country should contain spending to save abroad at least half of the revenues it receives over the first several years of the boom. Saving will accumulate to substantial levels even if the motivation is only to stabilize spending over long cycles. They would be higher if limited oil resources require saving for the postcycle period, or if absorption constraints bite sharply over the entire price cycle.

Permanent income projections should therefore estimate future revenues conservatively. Borrowing against future oil revenues is extremely risky. 
Countries facing external credit constraints and with a high rate of return to domestic investment might reasonably advance spending relative to the levels set by a permanent income approach. But this needs to be done with caution, particularly if spending booms will be large enough to cause absorption bottlenecks or expose the country to the risk of a large fall in domestic demand. The most favorable conditions for advancing spending are therefore when the windfall is modest and at the same time expected to continue for an extended period.

Spending decisions are political however. Governments may be myopic but if that is the only problem they will need to be very myopic indeed to cause much harm. Moderate levels of discounting will not shift the spending decision much because of the very high costs of excessive boom-time absorption. Worse is when decision-makers do not factor in absorption constraints (possibly because they value spending programs for their corruption opportunities rather than effectiveness) or macroeconomic adjustment costs. This combination can induce huge macroeconomic cycles and is fatal for welfare. Developing an informed consensus on the opportunities and the risks is therefore essential. Even with an engaged government, the difficulty for a new exporter will be how to do this without creating euphoric expectations of enormous immediate income gains. Transparency will be critical for reaching a broad consensus on policies, including the need to provide some comfort to citizens that savings made when prices and oil rents are high are not going to be stolen by successor governments.

The second question addressed the issue of oil wealth absorption and distribution. Many countries face political pressures to share part of their oil rents with citizens, and while oil rents accrue, in the first instance, mostly to producer governments, countries have a rich range of options for absorbing them. They can finance public investment or recurrent spending, or transfer oil rents to citizens and the private sector in a number of ways to encourage private investment, consumption or saving. Options include lowering non-oil taxes, price subsidies, and a range of transfer programs, communal or individual, conditional or unconditional, categorical or universal.

All options have political implications, and some will appeal to governments more than others depending on their incentives and motives. From an economic side they also have strengths and weaknesses, including from the perspectives of efficiency (deadweight losses), equity, sustainability, and the potential impact on accountability. The mechanisms used by many governments, including price subsidies, are indirect and usually inefficient. The option of reducing non-oil taxes offers the possibility of using this window to lower rates, widen the tax base and improve tax administration, but countries seem to have allowed the quality of tax collection to deteriorate. Few countries have yet ventured towards transparent dividend payments to citizens, but some have begun to express more interest in this alternative. This appears to be a promising area for further research, especially if transfers can be combined with incentives to invest in human capital, an essential complement to natural resource wealth.

A number of resource exporters offer lessons in how to diversify exports away from a dominant resource. The essentials include a reasonably stable macro-economy with restraint in overall spending, a reasonably open trade regime, and investment programs 
that successfully bring down production costs in the non-resource tradable sectors and increase their capabilities. The more successful cases, such as Malaysia, Indonesia and Chile have also benefited from diversified resource bases however, and the options will be more constrained for some countries. For example, despite good management and long efforts, Botswana has not succeeded in creating a competitive manufacturing sector.

Finally, what can be said about the more successful resource-rich developing countries beyond the usual prescription of "good governance"? While the list is modest, these countries have managed to restrain spending levels to avoid major booms and busts, and also to spend relatively effectively. A few countries, such as Botswana, plausibly owe their success to a strong initial institutional base which developed before the resource sector. But a number of countries with less favorable initial conditions have also been successful, such as Chile, Malaysia, and Indonesia during the earlier periods of the Suharto regime. These cases suggest some common elements in success. They include a widely shared concern to preserve social and economic stability as well as to grow rapidly; a credible and stable technocracy that engages closely with leaders and elected officials; and influential non-oil export sectors conscious of the dangers posed by unrestrained boom spending out of oil income. It has also sometimes been useful to identify savings with an explicit objective, to help citizens to better understand the need for it. While there is probably some institutional threshold below which it is unlikely that countries will benefit from oil wealth, conditions do not have to be perfect for far-sighted leadership and an engaged technocracy to ensure that oil rents are a blessing rather than a curse.

While this paper has not focused on the implications for external development partners, players, some implications do emerge from the analysis. One is the need to stand back from direct conditionality, especially given its limited leverage in resource-rich settings. Countries can be helped through the sharing of experience and open discussion, whether on approaches to saving revenues and on spending options. Standardized codes of conduct, such as the Natural Resource Charter can also be useful in providing a common reference point. Partners could help more directly in the design and management of savings facilities, and perhaps through activities which reduce some of the longer-run disincentives to using hedging and options, such as counterparty risk. Efforts will also be needed to identify, inform and strengthen potential domestic constituencies to support prudent and efficient policies, without which there is little prospect of diversification. Donors tend to focus on such activities during the booms, when the issue of natural wealth garners most attention. But it is then often too late - the foundations need to be prepared during the bust. 


\section{References}

Abidin, Mahani Z. 2001. "Competitive Industrialization with Natural Resource Abundance: Malaysia", in Richard M. Auty (ed.), Resource Abundance and Economic Development (Oxford University Press, Oxford).

Acemoglu Daron, Simon Johnson and James A. Robinson. 2003. "An African Success Story: Botswana" in Rodrik, Dani (ed) In Search of Prosperity: Analytical Narratives on Economic Growth, Princeton University Press.

Augero Jorge, Michael Carter and Ingrid Woolard. 2007. "The Impact of Unconditional Cash Transfers on Nutrition: the South African Child Support Grant" IPC Working Paper No. 39.

Auty, Richard. 1990. Resource-based industrialization: Sowing the oil in eight developing countries Clarendon Press, Oxford, UK,

Baird, Sarah, Craig Mcintosh and Berk Ozler. 2010. "Cash or Condition? Evidence from a Randomized Cash Transfer Program World Bank Policy Research Working Paper No 5259, March

Behrman, Jere R. Piyali Sengupta and Petra Todd. 2005. Progressing through PROGRESA: An Impact Assessment of a School Subsidy Experiment in Rural Mexico. Economic Development and Cultural Change, 54:1, 237-275.

Benaventa, Jose. 2006. "Wine Production in Chile" in Chandra, Vandana (ed) Technology, Adaptation and Exports: How some Developing Countries Got it Right, World Bank.

Birdsall, N. and A. Subramanian. 2004. "Saving Iraq from Its Oil.” Foreign Affairs 83(4): 77-89.

Bornhorst Fabian, Sanjeev Gupta and John Thornton. 2008. "Natural Resource Endowments, Governance and the Domestic Revenue Effort: Evidence from a Panel of Countries" IMF Working Paper WP/08/170

Brautigam, Deborah, Fjeldstad Odd-Helge and Moore Mick (eds) 2008, Taxation and State-Building in Developing Countries Cambridge University Press

Budina Nina and Sweder van Wijnbergen. 2008. "Managing Oil Revenue Volatility in Nigeria: The Role of Fiscal Policy". Chapter 10 in edds. Delfin and Page, "Africa at a Turning Point?" World Bank.

Collier, Paul \& Venables, Anthony J. 2008. "Illusory Revenues: Tariffs in ResourceRich and Aid-Rich Economies," CEPR Discussion Papers, 6729, C.E.P.R. Discussion Papers. 
Corporate Watch. 2006. "Corporate Identity: A critical analysis of private companies' engagement with the identity cards scheme". Oxford Greenprint, January.

Cover, James P. 1992. "Asymmetric Effects of Positive and Negative Money-Supply Shocks”. The Quarterly Journal of Economics, 107(4), 1261-1282.

Cowper, Steve 2007 “A Word to the Wise: Managing Alaska's Oil Wealth" in JohnsonCalari, Jennifer and Malan Rietveld (Eds). Sovereign Wealth Management BlackRock publishers

Coxhead, Ian. 2007. “A New Resource Curse? Impacts of China's Boom on Comparative Advantage and Resource Dependence in Southeast Asia" World Development 35: 7, 1099-1119.

Davis, Jeffrey M., Rolando Ossowski and Anna Fedelino (eds). 2003. Fiscal Policy Formulation and Implementation in Oil Producing Countries. IMF, Washington DC.

Eifert Benn, Alan Gelb and Nils Tallroth. 2003. "The Political Economy of Fiscal Policy and Economic Management in Oil-Exporting Countries" in Davis, J.M et al.

Elbadawi, Ibrahim and Linda Kaltani. 2007. "The macroeconomics of oil booms: Lessons for Sub-Saharan Africa," Chapter 3 in Mathew Martin (ed). Managing Commodity Booms in Sub-Saharan Africa. The African Economic Research Consortium, Nairobi, Kenya. (Forthcoming).

El-Hamidi, Fatma. 2003. "Poverty and Labor Supply of Women: Evidence from Egypt" Paper presented to the Tenth Annual Conference of the ERF, 16-18 December, University of Pittsburgh, PA.

Engel, Eduardo and Rodrigo Valdés. 2000. “Optimal Fiscal Strategy for Oil Exporting Countries”. IMF Working Paper No. 00/118.

Falkinger, Josef and Volker Grossmann. 2005. "Distribution of Natural Resources, Entrepreneurship, and Economic Development: Growth Dynamics with Two Elites. CESIFO Working Paper 1562.

Fiszbein, Ariel and Norbert Schady 2009, Conditional cash Transfers: Reducing Present and Future Poverty World Bank, Washington DC.

. Fjelstad Odd-Helge and Michael Moore. 2009. " Revenue Authorities and Public Authority in Sub-Saharan Africa” Journal of Modern African Studies, forthcoming.

Frankel Jeffrey A. 2010, “The Natural Resource Curse: A Survey” NBER Working Paper 15836, March.

Gelb, Alan. 1988. Oil Windfalls: Blessing or Curse Oxford University Press. 
Gelb, Alan and Sina Grasmann. 2008. "Confronting the Oil Curse" Paper presented to AFD/EUDN Conference, Paris, November.

Gylfason, Thorvaldur, Natural Resources and Economic Growth: From Dependence to Diversification (December 2004). CEPR Discussion Paper No. 4804.

Hamilton, James D. 2008. “Understanding Crude Oil Prices” University of San Diego, Draft June 4.

Hausmann, Ricardo. 2001. "Venezuela's Growth Implosion: A neo-Classical Story?" Paper prepared for the seminar on Analytic Country Studies on Growth, Harvard University April 20-21.

Hausmann Ricardo and Roberto Rigobón. 2003. "An Alternative Interpretation of the Resource Curse: Theory and Policy Implications" in Davis et al (eds) 2003

Heinmiller, B. Timothy. 2009. Path dependency and collective action on common pool governance. International Journal of the Commons, 3 (1)

Humphreys, Macartan, Jeffrey Sachs, and Joseph Stiglitz, eds. 2007. Escaping the Resource Curse. New York: Columbia University Press

International Monetary Fund. 2007. The Role of Fiscal Institutions in Managing the Oil Revenue Boom FAD, March 5

Kandil, Magda E. 1999. "The Asymmetric Stabilizing Effects of Price Flexibility: Historical Evidence and Implications". Applied Economics, 31(7), 825-839.

Kandil, Magda E. 2006. "Asymmetric Effects of Aggregate Demand Shocks Across U.S. Industries: Evidence And Implications”. Eastern Economic Journal, 32(2), 259-283.

Karl, Terry L.1997. The Paradox of Plenty: Oil Booms and Petro-States. Berkeley: University of California Press.

Karl, Terry L. 2003. Bottom of the Barrel: Africa's Oil Boom and the Poor. Catholic Relief Services, June.

Karl, Terry Lynn. 2007. "Ensuring Fairness: The Case for a Transparent Fiscal Contract" in Humphreys et al.

Karl, Terry L. 2007a. "Oil-Led Development: Social, Political, and Economic Consequences" CDDRL Working Paper 80, Stanford University, January.

Katz, Jorge. 2006. "Salmon Farming in Chile" in Chandra (ed). 
Knack, Stephen. 2008. "Sovereign Rents and the Quality of Tax Policy and Administration" World Bank Policy Research Report 4773 , November.

Leiderman Daniel and William Maloney (eds) 2007 Natural Resources: Neither Curse

Nor Destiny World Bank and Stanford University Press.

Lewis, Peter. 2007. Growing Apart: Oil, Politics, and Change in Indonesia and Nigeria, University of Michigan Press.

McSharry, Brandon. 2006. "The Political Economy of Oil in Equatorial Guinea", African Studies Quarterly, 8(23).

Moffitt, Robert 2002. "Welfare Programs and Labor Supply” NBER Working Paper No 9168, September.

Moreen, Amber Linea. 2007. "Resource Curse: Prioritizing Policy Interventions in Countries with Large Extractive Industries," PhD Dissertation, Pardee RAND Graduate School.

Moss, Todd and Lauren Young 2009 "Saving Ghana from its Oil: The Case for Direct Distribution” CGD Discussion Paper No 186, November.

Organization for Economic Co-operation and Development. 2008. Governance, Taxation and Accountability. Issues and Practices. DAC Guidelines and Reference Series. Retrieved 01.13.2009 from http://www.oecd.org/dataoecd/52/35/40210055.pdf

Okonjo-Iweala Ngozi, and Philip Osafo-Kwaako. 2007. "Nigeria's Economic Reforms: Progresses and Challenges," The Brookings Institution, March.

Palley, T. 2003. "Combating the Natural Resource Curse with Citizen Revenue Distribution Funds." Foreign Policy in Focus (December): 1-12.

Platteau, Jean-Philippe. 2004. "Monitoring Elite Capture in Community-Drive Development". Development and Change, 35(2), April.

Rasiah, Rajah. 2006. “Explaining Malaysia's Export Expansion in Palm Oil and Related Products" in Chandra (ed).

Reinikka, Ritva. 2001. "Recovery in Service Delivery: Evidence from Schools and Clinics" in Reinikka Ritva and Paul Collier (eds.), Uganda's Recovery: The Role of Farms, Firms and Government. Regional and Sectoral Studies, The World Bank, Washington, D.C.

Rietveld, Malan and Robert Pringle. 2007. "The Evolution of Sovereign Wealth Management" in Johnson-Calari, Jennifer and Malan Rietveld (Eds). Sovereign Wealth Management BlackRock publishers. 
Ross, Michael. 2007. "How Mineral-Rich States Can Reduce Inequality” In Escaping the Resource Curse, Jeffrey Sachs, Joseph Stiglitz, and Macartan Humphreys eds., 2007

Ross, Michael. 2008. "Oil, Islam and Women" American Political Science Review, Volume 102 No 1, February.

Salehi-Isfahani, Djavad. 2002. Microeconomics of Growth in Iran: The Role of Households". Virginia Tech, mimeo September.

Sandbu, M. E. 2006. “Taxable Resource Revenue Distributions: A Proposal for Alleviating the Natural Resource Curse.” World Development 34(7): 1153-70.

Soares, Fábio Veras, Rafael P. Ribas and Rafael G. Osório. 2007. Evaluating the Ipmact of Brazil's Bolsa Família: Cash Transfer Programmes in Comparative Perspective. International Poverty Centre Evaluation Note, 1. International Poverty Centre.

Stiglitz, Joseph. E. 2006. “Making Globalization Work”. New York: W.W. Norton \& Company.

van der Ploeg, Frederick and Anthony J Venables. 2009. "Harnessing Windfall Revenues: Optimal policies for resource-rich developing economies". OxCarre Research Paper, No. 2008-09.

Woolard, Ingrid and Murray Leibbrandt 2010, "The Evolution and Impact of Unconditional Cash Transfers in South Africa" Paper presented to the ABCDE Conference, Stockholm, Sweden, May.

World Bank. (2004). "Unlocking the Employment Potential in the Middle East and North Africa" Washington, D.C.: World Bank.

World Bank. (2007). Botswana Investment Climate Assessment. Washington, D.C.: World Bank. 